\title{
Predicting Jellyfish Strandings in the Moroccan North-West Mediterranean Coastline
}

\section{Majda Aouititen}

Laboratory of Environment, Biodiversity and Ecology, Faculty of Sciences, Abdelmalek Essaadi University, Tetouan, Morocco and College of Nature Conservation, Beijing Forestry University, Beijing, China

\section{Ratiba Bekkali}

\section{Driss Nachit}

Laboratory of Environment, Biodiversity and Ecology, Faculty of Sciences, Abdelmalek Essaadi University, Tetouan, Morocco

\section{Xiaofeng Luan}

College of Nature Conservation, Beijing Forestry University, Beijing, China

\section{Mohammed Mrhraoui}

National Institute of Fisheries Research Tangier-M'Diq-Morocco

\begin{abstract}
In the recent years, the frequency and the geographic distribution of jellyfish blooms have been increased in the Mediterranean north-west coastline of Morocco. Since 2011 this area has been subjected to successive blooms and stranding of Pelagia noctiluca. Our research was aimed to study the reasons of jellyfish blooms and to predict their stranding in our coastline. We have evaluated three parameters that we are suspecting to be responsible of Jellyfish blooms and stranding on the northern coast of the Mediterranean Sea in Morocco. The evaluation of the relations between sea surface temperature, waves height and the wind direction causing the stranding of Jellyfish, demonstrated that the correlation scores were found to be statistically significant with $\mathrm{r}(33)=0.445, \mathrm{p}<0.01$, for sea surface temperature $\left({ }^{\circ} \mathrm{C}\right)$ and $\mathrm{r}(33)=0.694, \mathrm{p}<0.001$ for waves height $(\mathrm{m})$. Moreover a one-way analysis of variance (ANOVA) was calculated on wind direction causing stranding of jellyfish; the analysis was found to be very significant, $F$ $(1,31)=25.823, p=0.001$.
\end{abstract}

Keywords: Pelagia noctiluca; Jellyfish; Stranding; Morocco; Mediterranean north-west coastline. 


\section{Introduction}

Trends in $\boldsymbol{P}$. noctiluca populations in the Mediterranean have been recently reviewed (Broth et al. 2012, Condon et al. 2013). The periodic occurrence of P. noctiluca in the western Mediterranean was first reported by Goy et al. in 1989, Dr. Goy reconstructing a time series of the occurrence of $\boldsymbol{P}$. noctiluca dating back to 1775 . Long-term climate fluctuations have been correlated with jellyfish abundance in Mediterranean waters (Molinero et al. 2005, 2008). The North Atlantic climate variability is significantly related to long-term changes in zooplankton functional groups, including Pelagia noctiluca, in the NW Mediterranean (Molinero et al. 2008). Physical forcing has also been responsible for coastal or inshore stranding in the Adriatic Sea (Maretic et al, 1987; Benović 1991; Legović1991; Zavodnik 1991; Malej and Malej 2004). In shallow coastal waters wind, currents and tides have been the main drivers, allowing for huge accumulations of medusae (Zavodnik D, 1987). Jellyfish spatiotemporal dynamics are highly variable, as well the blooms which occur irregularly are difficult to predict (Boero et al. 2008, Brotz and Pauly 2012). Pelagia noctiluca (Forsskål 1775) is the most common jellyfish species in the Mediterranean waters; it is widely distributed from the warm subtropical waters of the Gulf of Mexico and the Mediterranean Sea to the temperate waters of the North Sea (Russell 1970; Graham et al. 2003; Purcell 2005; Licandro et al. 2010) and up to $4^{\circ} \mathrm{C}$ of latitude (Doyle et al. 2008; Bastian et al. 2011).

Pelagia noctiluca is an important non selective planktonic predator (Larson 1987; Morand et al. 1987; Sandrini and Avian 1989; Giorgi et al. 1991; Daly Yahia et al. 2010; Rosa et al. 2013) feeding on almost all types of zooplankton and ichthyoplankton (Giorgi et al. 1991; Zavodnik 1991; Malej et al. 1993). In fact, many fish compete for the same zooplankton prey as jellyfish (Purcell and Arai 2001, Purcell et al., 2007 ); moreover, fish are also predators of jellyfish, with benthic including reef fish species ingesting polyps, as well as pelagic fish species eating ephyrae and small individuals (Graham, 2001). However, the declination of such fish opens up ecological space for jellyfish proliferations. Moreover, coastal eutrophication encourage phytoplankton blooms that can ultimately lead to jellyfish outbreaks (Purcell et al. 2007). The greater tolerance of polyps and medusa than fish to lowoxygen conditions ensures that jellyfish survive, even reproduce during hypoxic events, which fish are unable to do; such 'dead zones' are thought to favor jellyfish (Lynam et al. 2004). Higher temperatures also accelerate medusa growth and ephyrae production (Kevin and Raskoff 2001). Jellyfish appear to be sensitive to climate variability, with their abundance being related to large-scale climate indices such as the North Atlantic Oscillation (NAO) (Lynam et al. 2004), El Nino Southern Oscillation (Kevin and Raskoff 2001), and the Pacific Decadal Oscillation (Anderson and Piatt 1999). 


\section{Material and Methods \\ Study area}

$M^{\prime}$ Diq having as geographical coordinates $35^{\circ} 41^{\prime} \mathrm{N} 5^{\circ} 19^{\prime} 31 \mathrm{~W}$, is a seaside resort; the population lives almost exclusively on fishing and summer tourism activities and it hosts more than 100,000 tourists each year. M'Diq is located $7 \mathrm{~km}$ from Tetouan city, and it's bounded on the north by Fnideq municipality, on the south by Mellaliyine commune, on the west by Alleyine commune and on the east by the Mediterranean Sea. M'Diq covers an area of 480 hectares of which 153 hectares is urbanized (Figure 1). The selection of this area is based on the presence of jellyfish blooms along the beaches.

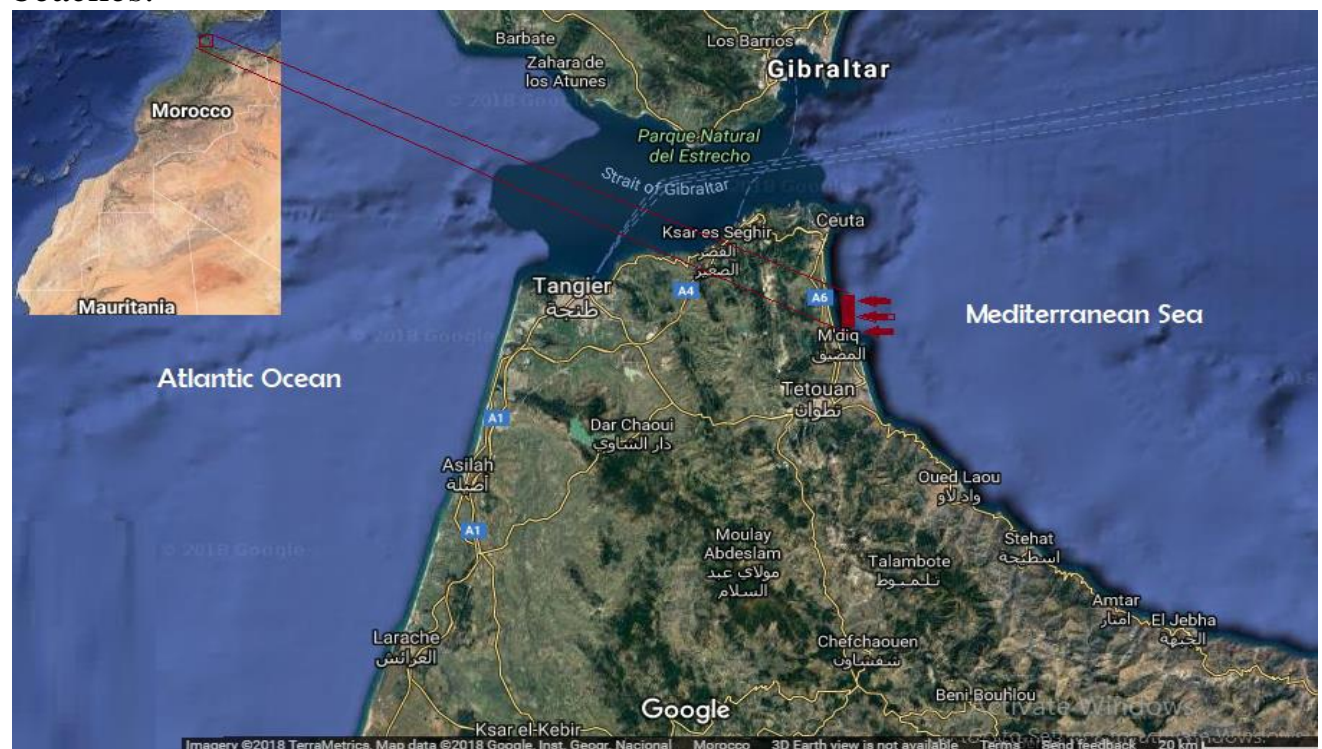

Figure 1: Geographical location of our study area (Source Google Map)

\section{Sampling Strategy}

Jellyfish survey strategy used for our study was inspired of the method used by Doyle (Doyle et al. 2008) for the study of jellyfish species repartition across the Irish and Celtic Sea shores. In this study, the survey method consisted of walking along a beach transect during low tide. We walked along the water edge to the end of the transect and returned along the tide upper limit, while counting and identifying stranded Jellyfish. In order to have consistency between surveys, this transect situated between low tide and high tide limit was chosen for each survey. Transects start and end points were recorded and are described as it follows: Start point: $35.683040 " \mathrm{~N},-5.318971$ "W End point: 35.817096"N, -5.351673"W Length (m): 989. We did use the Quadrate method to calculate the density of jellyfish stranded per square meter. The study was conducted from June 2011 until December 2017 (Figure 2). 


\section{Jellyfish identification \& Environmental variables}

Pelagia noctiluca is the only jellyfish species found stranded in the Mediterranean north-west coastline of Morocco. We have used Russell (Russell, 1970) taxonomic for the identification of the jellyfish we have found. Sea surface temperature was recorded in situ (independent points) for each survey. Temperature has been recorded from June 2011 until December 2017. These readings were recorded every day and a monthly average was used for correlation analyses with jellyfish abundance.

In addition, measures of wave's height as well as wind direction were obtained from PREVIMER web-sites. These tow parameters have been recorded every day of the six years and they were used for correlation analyses to find out if they are causing Jellyfish stranding in our coastline.

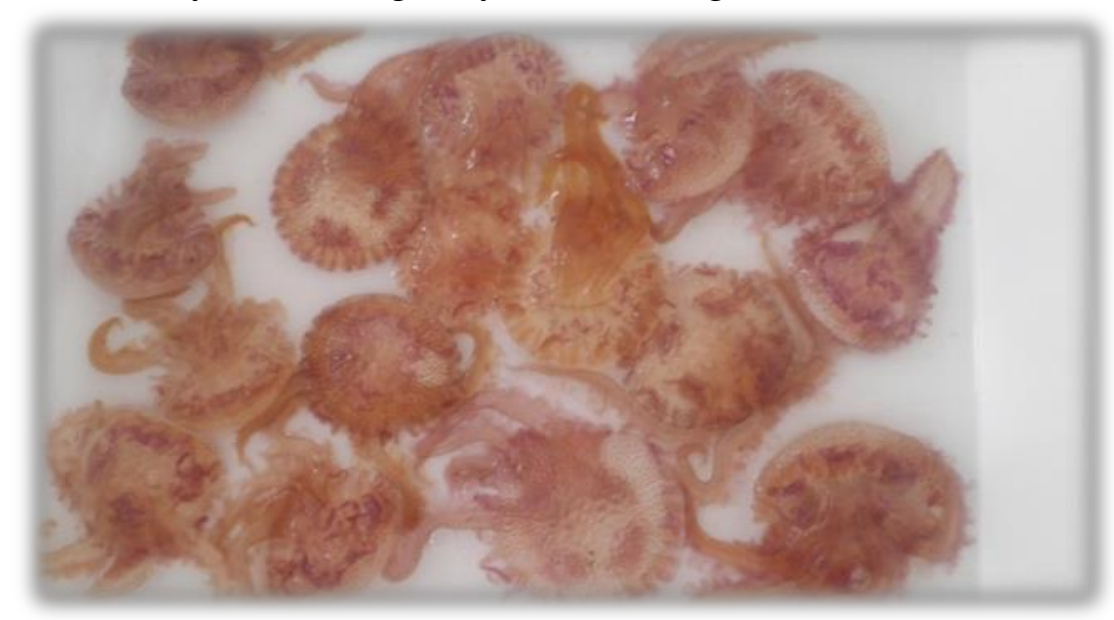

Figure 2: Pelagia noctiluca sample (source Majda AOUITITEN)

\section{Cluster analysis}

Part of the data obtained from the samples was statistically calculated and analyzed using Microsoft Excel software. However Pearson Correlation analysis were used to determine whether there is a relationship between the quantitative variables which are sea surface temperature, waves height and Jellyfish stranding. In addition, ANOVA test was used to determine if there is a relationship between the quantitative variable wind direction with Density of jellyfish stranded; this tow test was statistically calculated, analyzed and compared using SPSS software.

\section{Results}

\section{Physical parameters of water}

Analysis of the samples of water in our zone of study has yielded several physical and chemical characteristics of the environment where Pelagia noctiluca stranded. Between June 2011 and December 2017 one type 
of Jellyfish species was encountered during beach surveys, which is Pelagia noctiluca (Forsskål 1775). The total number of stranded jellyfish observed each year was: 1000 ind between June and September 2011, 1100 ind between June and October 2012, no blooms or strandings found in 2013, 170 ind between April and October 2014, 990 ind from Jan- August till October 2015, 270 ind from August till September 2016 and 2610 ind from June till December 2017. The overall abundance of encountered stranded Pelagia noctiluca demonstrated a fluctuating pattern during summer. Actually physical water measurements including the temperature show that the appearance of the jellyfish Pelagia noctiluca starts in our coastline at a sea surface temperature of $21^{\circ} \mathrm{C}$, the maximum abundance is reached at a sea surface temperature of $25.61^{\circ} \mathrm{C}$, then $\boldsymbol{P}$. noctiluca starts to disappear at a sea surface temperature of $16^{\circ} \mathrm{C}$; moreover we have observed that when the waves have the height between $1.20 \mathrm{~m}$ to $2 \mathrm{~m}$, we have probably appearance of Pelagia noctiluca (Figure 3).

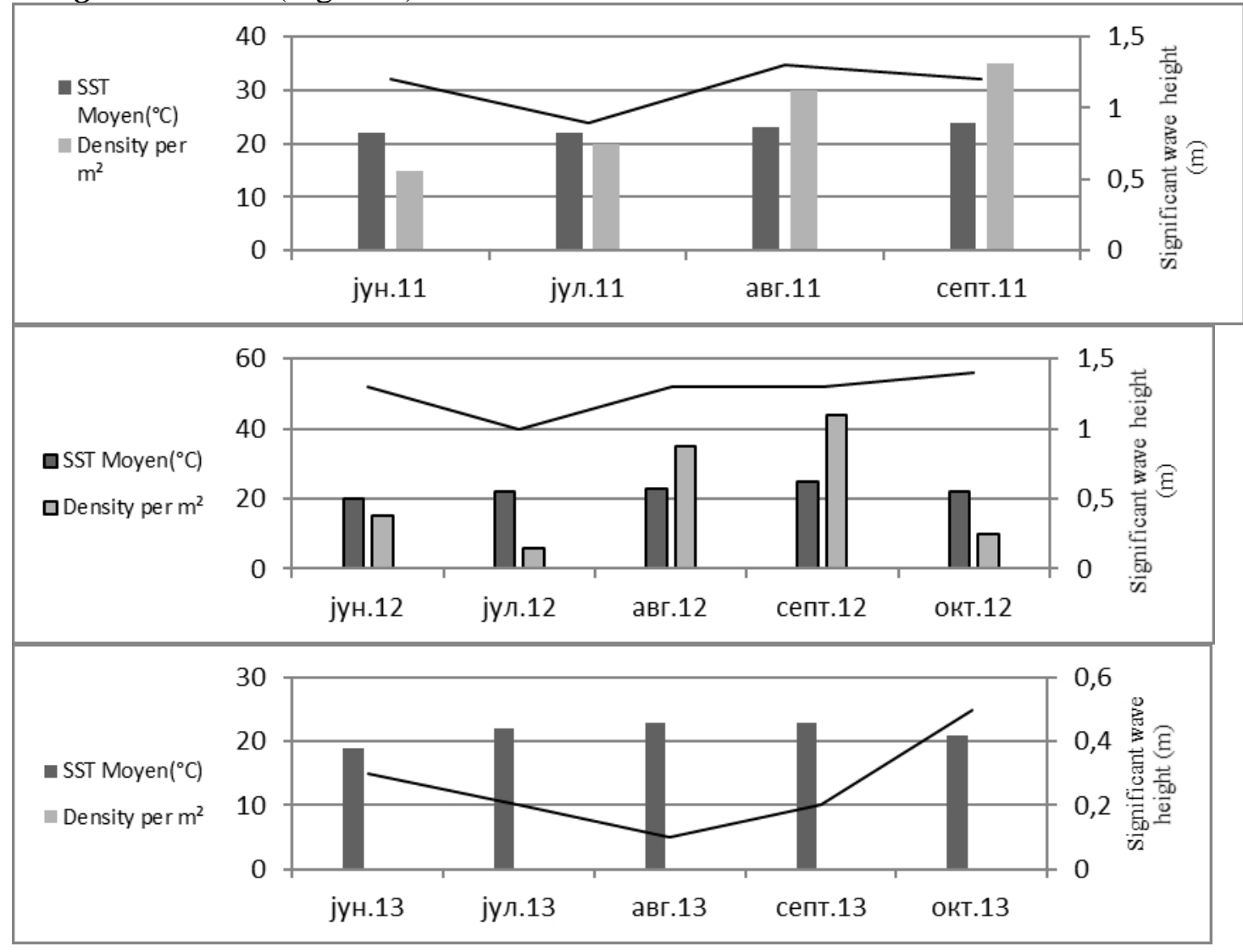




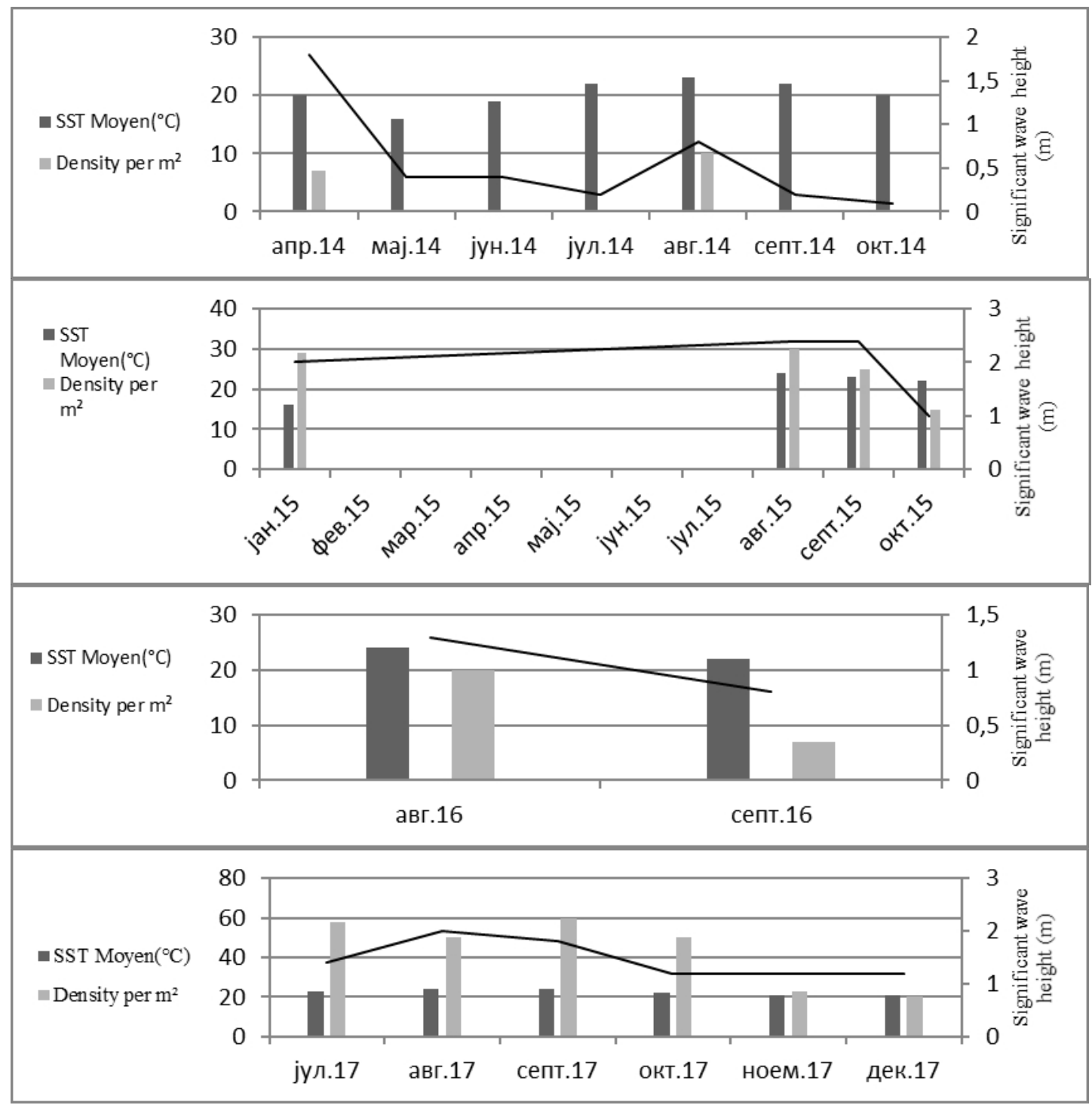

Figure 3: Monthly variation of (SST) sea surface temperature $\left({ }^{\circ} \mathrm{C}\right)$, waves height $(\mathrm{m})$ and the density of jellyfish stranded per $\mathrm{m}^{2}$; (from 2011 until 2017).

\section{Wind direction}

We have observed that when the east wind blows on our beach, we have probably appearance of Pelagia noctiluca and if it's not, we will not found any jellyfish stranding. This was observed in the year of 2013: no jellyfish blooms or stranding have been recorded in to our coast, even if the sea surface temperature was [in June: $18.7^{\circ} \mathrm{C}$, July: $22^{\circ} \mathrm{C}$, August: $23^{\circ} \mathrm{C}$, September: $24^{\circ} \mathrm{C}$, October: $22^{\circ} \mathrm{C}$ ] high enough to have blooms of jellyfish (Figure 4). 

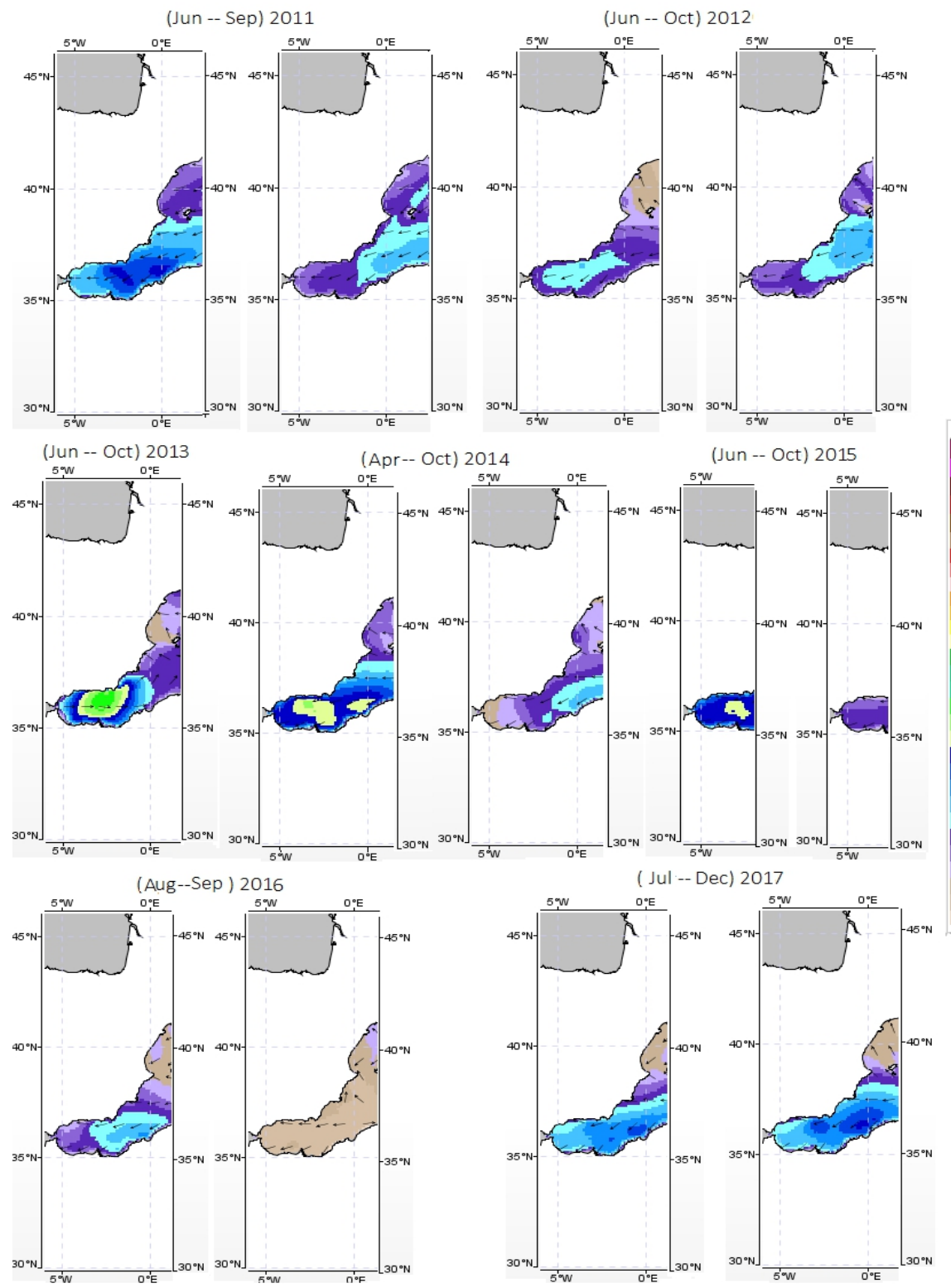

Figure 4: Satellite-derived sea-surface significant wave's height and wind direction (model WAVEWATCH III following Douglas Sea and swell scale protocol, 1921). Instrument for the stranding months from June 2011 to December 2017.

\section{Statistic analysis results}

Statistical analysis was carried out using statistical tests software package, with the intention of studying the relation between sea surface temperature, sea waves height and Jellyfish stranding and to determine whether there is a relationship or not. Pearson Correlation test shows that the density of jellyfish stranded and sea surface temperature have a statistically 
significant linear relationship r $(33)=0.445, \mathrm{p}<0.01$ (Table 1$)$, meaning that these variables tend to increase together (greater density of jellyfish stranded is associated with greater sea surface temperature). Moreover, we have found that the relationship between the density of jellyfish stranded and sea waves height was a positive correlation between the two variables, $r=+0.694, n=$ 33, $\mathrm{p}=0.001$ (Table 2).

Table 1: Relation of correlation between sea surface temperature and the density of Pelagia noctiluca stranded

Correlations

\begin{tabular}{|cc|r|r|}
\hline & & $\begin{array}{c}\text { Density of jellyfish } \\
\text { stranded per } \mathrm{m}^{2}\end{array}$ & $\begin{array}{c}\text { Sea Surface } \\
\text { Temperature }\left({ }^{\circ} \mathrm{C}\right)\end{array}$ \\
\hline Density of jellyfish stranded per & Pearson Correlation & 1 & $.445^{* *}$ \\
$\mathrm{~m}^{2}$ & Sig. (2-tailed) & .010 \\
& $\mathrm{~N}$ & 33 & 33 \\
\hline Sea Surface Temperature $\left({ }^{\circ} \mathrm{C}\right)$ & Pearson Correlation & $.445^{* *}$ & 1 \\
& Sig. (2-tailed) & .010 & 33 \\
& $\mathrm{~N}$ & 33 & 33 \\
\end{tabular}

**. Correlation is significant at the 0.01 level (2-tailed).

Table 2: Relation of correlation between sea wave's height and the density of Pelagia noctiluca stranded.

Correlations

\begin{tabular}{|cc|r|r|}
\hline & & $\begin{array}{c}\text { Density of jellyfish } \\
\text { stranded per } \mathrm{m}^{2}\end{array}$ & $\begin{array}{c}\text { Sea waves height } \\
(\mathrm{m})\end{array}$ \\
\hline Density of jellyfish stranded per & Pearson Correlation & 1 & $.694^{* *}$ \\
$\mathrm{~m}^{2}$ & Sig. (2-tailed) & & .000 \\
& $\mathrm{~N}$ & 33 & 33 \\
\hline Sea waves height $(\mathrm{m})$ & Pearson Correlation & $.694^{* *}$ & 1 \\
& Sig. (2-tailed) & .000 & 33 \\
& $\mathrm{~N}$ & 33 & 33 \\
& & &
\end{tabular}

**. Correlation is significant at the 0.01 level (2-tailed).

A one-way analysis of variance (ANOVA) was calculated on wind direction causing stranding of jellyfish. The analysis was significant, $F(1,31)$ $=25.823, p=0.001$ (Table 4). East wind cause the stranding of jellyfish $(M=$ $26.70, S D=16.463)$ more than the West wind $(M=0.00, S D=0.000)$ (Table 3). 
Table 3: Descriptive relation between wind direction and the density of Pelagia noctiluca stranded.

Descriptives

Density of jellyfish stranded per $\mathrm{m}^{2}$

\begin{tabular}{|c|c|c|c|c|c|c|c|c|}
\hline & \multirow[b]{2}{*}{$\mathrm{N}$} & \multirow[b]{2}{*}{ Mean } & \multirow[b]{2}{*}{$\begin{array}{c}\text { Std. } \\
\text { Deviation }\end{array}$} & \multirow[b]{2}{*}{$\begin{array}{l}\text { Std. } \\
\text { Error }\end{array}$} & \multicolumn{2}{|c|}{$\begin{array}{l}95 \% \text { Confidence Interval } \\
\text { for Mean }\end{array}$} & \multirow[b]{2}{*}{$\underset{\mathrm{m}}{\operatorname{Minimu}}$} & \multirow[b]{2}{*}{$\underset{\mathrm{m}}{\operatorname{Maximu}}$} \\
\hline & & & & & $\begin{array}{l}\text { Lower } \\
\text { Bound }\end{array}$ & $\begin{array}{l}\text { Upper } \\
\text { Bound }\end{array}$ & & \\
\hline East & 23 & 26.70 & 16.463 & 3.433 & 19.58 & 33.81 & 6 & 60 \\
\hline West & 10 & .00 & .000 & .000 & 0.00 & .00 & 0 & 0 \\
\hline Total & 33 & 18.61 & 18.481 & 3.217 & 12.05 & 25.16 & 0 & 60 \\
\hline
\end{tabular}

Table 4: ANOVA test to determine the relationship between wind direction and the density of Pelagia noctiluca stranded.

ANOVA

Density of jellyfish stranded per $\mathrm{m}^{2}$

\begin{tabular}{|c|r|r|r|r|r|}
\hline & Sum of Squares & \multicolumn{1}{|c|}{ df } & Mean Square & F & Sig. \\
\hline Between Groups & 4967.009 & 1 & 4967.009 & 25.823 & 0.000 \\
Within Groups & 5962.870 & 31 & 192.351 & & \\
Total & 10929.879 & 32 & & & \\
\hline
\end{tabular}

\section{Conclusion and discussion}

The causes of the jellyfish blooms and strandings around Moroccan North-West Mediterranean coastal waters is poorly understood. Starting in 2011 until 2017, our study aimed to evaluate the reasons of jellyfish blooms as well as their strandings, based on the evaluation of three parameters (sea surface temperature, sea waves height and wind direction). We have found that we can combine the observations of sea surface temperature, sea waves height and wind direction to predict whether we will have stranding of Pelagia noctiluca on our coastline or not. Between June 2011 and December 2017, one type of Jellyfish species was encountered in our area of study which is Pelagia noctiluca. Actually, the appearance of this jellyfish starts on our coastline at a sea surface temperature of $21^{\circ} \mathrm{C}$, the maximum abundance is reached at a sea surface temperature of $25.61^{\circ} \mathrm{C}$, then $\boldsymbol{P}$. noctiluca starts to disappear at a sea surface temperature of $16^{\circ} \mathrm{C}$. Experiments reveal that temperature affects the activity (pulsation rate) of this species; specifically extreme temperatures, $<11{ }^{\circ} \mathrm{C}$ and $>26^{\circ} \mathrm{C}$, cause decreased activity (Malej and Malej 2004). Moreover we have observed that when the waves have the height between $1.20 \mathrm{~m}$ to $2 \mathrm{~m}$, and when the east wind blows on our beach, we have probably stranding of Pelagia noctiluca. Physical forcing (wind and current direction) was thought to determine the presence of Pelagia noctiluca in inshore and offshore waters in the northern Adriatic Sea (Vucetic T, 1984). But if it's not, we will not found any jellyfish stranding; this was observed in 
2013: no jellyfish blooms or stranding have been recorded on our coast, even if the sea surface temperature was [in June: $18.7^{\circ} \mathrm{C}$, July: $22^{\circ} \mathrm{C}$, August: $23^{\circ} \mathrm{C}$, September: $24^{\circ} \mathrm{C}$, October: $22^{\circ} \mathrm{C}$ ] high enough to have blooms of jellyfish. The correlation scores for all the parameters were found to be statistically significant with $\mathrm{r}(33)=0.445, \mathrm{p}<0.01$, for sea surface temperature $\left({ }^{\circ} \mathrm{C}\right)$ and $\mathrm{r}(33)=0.694, \mathrm{p}<0.001$ for waves height $(\mathrm{m})$ as well as a one-way analysis of variance (ANOVA) calculated on wind direction found to be very significant, $F(1,31)=25.823, p=0.001$.

The beach stranding survey method proved to be applicable for the scale of the current research and is an important step in the understanding of jellyfish blooms and strandings predictions around the Moroccan North-West Mediterranean coastal.

As a final conclusion, we consider that the methodology presented in this study could be easily adapted and expanded along the Moroccan NorthWest Mediterranean coastal to predict Jellyfish strandings which will help us to reduce the number of people stung by jellyfish.

\section{Acknowledgment}

The authors would like to thank M'diq station of the National Institute of Fisheries Research (INRH) for its infrastructural and moral support and the anonymous reviewers for their comments on the draft of this manuscript.

\section{References:}

1. Anderson, PJ., Piatt, JF. (1999). Community reorganization in the Gulf of Alaska following ocean climate regime shift. Marine Ecology Progress Series 189: 117-123.

2. Bastian, T., Stokes, D., Kelleher, J.E., Hays, G.C., Davenport, J., Doyle, T.K. (2011). Fisheries bycatch data provide insights into the distribution of the mauve stinger (Pelagia noctiluca) around Ireland.

3. Benović, A. (1991). The aspect of jellyfi sh distribution in the Adriatic Sea. UNEP: Jellyfi sh blooms in the Mediterranean proceedings of the II workshop on jellyfi sh in the Mediterranean Sea MAP Tech Rep Ser, No. 47. UNEP, Athens, pp 41-50.

4. Boero, F., Bouillon, J., Gravili, C., Miglietta, M.P., Parsons, T., Piraino, S. (2008). Gelatinous plankton: irregularities rule the world (sometimes). Marine Ecology Progress Series 356: 299-310.

5. Brotz, L., Pauly, D. (2012). Jellyfish populations in the Mediterranean Sea. Acta Adriat 53: 213-232.

6. Condon, R.H., Duarte, C.M., Pitt, K.A., Robinson, K.L., Lucas, C.H., Sutherland, K.R., Mianzan, H.W., Bogeberg, M., Purcell, J.E., Decker, M.B., et al. (2013). Recurrent jellyfish blooms are a consequence of global oscillations. Proc. Natl. Acad. Sci. USA 110, 1000-1005. 
7. Daly, Yahia, M.N., Batistic, M., Lucić, D., Fernández de Puelles, M.L., Licandro, P., Malej, A., Molinero, J.C., Siokou Frangou, I., Zervoudaki, S., Prieto, L., Goy, J., Daly Yahia Kéfi, O. (2010). Are the outbreaks of Pelagia noctiluca (Forsskål, 147 1775) more frequent in the Mediterranean basin? In: Gislason A, Gorsky G (eds) Proceedings of the joint ICES/CIESM workshop to compare zooplankton ecology and methodologies between the Mediterranean and the North Atlantic (WKZEM). ICES Cooperative Research Report, pp 8-14.

8. Goy, J., Morand, P., Etienne, M. (1989). Long-term fluctuations of Pelagia noctiluca (Cnidaria, Scyphomedusa) in the western Mediterranean Sea. Prediction by climatic variables. Deep-Sea Res 36:269-279.

9. Doyle, T.K., De Haas, H., Cotton, D., Dorschel, B., Cummins, V., Houghton, J.D.R., Davenport, J., Hays, G.C. (2008). Widespread occurrence of the jellyfish Pelagia noctiluca in Irish coastal and shelf waters. J Plankton Res 30:963-968.

10. Giorgi, R., Avian, M., De Olazabal, S., Rottini-Sandrini, L. (1991). Feeding of Pelagia noctiluca in open sea. Jellyfish blooms in the Mediterranean. In: Proceedings of II workshop on jellyfish in the Mediterranean Sea. MAP Tech Rep Ser, 154 No. 47. UNEP, Athens, pp 102-111.

11. Graham, W.M. (2001). Numerical increases and distributional shifts of Chrysaora quinquecirrha (Desor) and Aurelia aurita (Linne) (Cnidaria: Scyphozoa) in the northern Gulf of Mexico. Hydrobiologia 451: 97111.

12. Graham, W.M., Martin, D.L., Martin, J.C. (2003). In situ quantification and analysis of large jellyfish using a novel video profiler. Mar Ecol Prog Ser 254:129-140.

13. Kevin, A. Raskoff (2001). The impact of El Nino events on populations of mesopelagic hydromedusae. Hydrobiologia 451: 121129.

14. Larson, R.J. (1987). A Note on the Feeding, Growth, and Reproduction of the Epipelagic Scyphomedusa Pelagia noctiluca (Forsskål). Biological Oceanography 4:447-454.

15. Legović, T. (1991). Causes, consequences and possible control of massive occurrences of jellyfish Pelagia noctiluca in the Adriatic Sea. UNEP: Jellyfish blooms in the Mediterranean proceedings of the II workshop on jellyfish in the Mediterranean Sea MAP Tech Rep Ser, No. 47. UNEP, Athens, pp 128-132.

16. Licandro, P., Conway, D.V.P., Daly Yahia, M.N., Fernandez de Puelles, M.L., Gasparini, S., Hecq, J.H., Tranter, P., Kirby, R.R. 
(2010). A blooming jellyfish in the northeast Atlantic and Mediterranean. Biol Lett 6: 688-691.

17. Lynam, C.P., Hay, S.J., Brierley, A.S .(2004). Interannual variability in abundance of North Sea jellyfish and links to the North Atlantic Oscillation. Limnology and Oceanography: 637-643.

18. Malej, A., Faganeli, J., Pezdič, J. (1993). Stable isotope and biochemical fractionation in the marine pelagic food chain: the 168 jellyfish Pelagia noctiluca and net zooplankton. Marine Biology 116: 565-570.

19. Malej, A., Malej, A.J. (2004). Invasion of the Jellyfi sh Pelagia noctiluca in the Northern Adriatic: a non-success story, In: Dumont H, Shiganova TA, Niermann U (eds) Aquatic invasions in the Black, Caspian, and Mediterranean Seas: the ctenophores Mnemiopsis leidyi and Beroe in the Ponto-Caspian and other aquatic invasions. Nato Science Series: 4. Earth and Environmental Sciences. Springer, Netherlands, pp 273-285.

20. Maretić, Z., Matic-Piantanida, D., Ladavac , J. (1987). The blooms of the jellyfish Pelagia noctiluca in the Mediterranean and Adriatic and its impact on human health. In: Proceedings of the 2nd workshop on jellyfish in the Mediterranean, Trieste, pp 260-267

21. Molinero, J.C., Ibanez ,F., Nival, P., Buecher, E., Souissi, S. (2005). North Atlantic climate and northwestern Mediterranean plankton variability. Limnol Oceanogr 50:1213-1220.

22. Molinero, J.C., Ibanez, F., Souissi, S., Buecher, E., Dallot, S., Nival, P. (2008). Climate control on the longterm anomalous changes of zooplankton communities in the Northwestern Mediterranean. Global Change Biol 14:11-26.

23. Morand, P., Carré, C., Biggs, D.C. (1987). Feeding and metabolism of the jellyfish Pelagia noctiluca (Scyphomedusae, Semaeostomae). Journal of Plankton Research 9:651-665.

24. Purcell, J.E., Arai, M.N. (2001). Interactions of pelagic cnidarians and ctenophores with fish: a review. Hydrobiologia 451: 27-44.

25. Purcell, J.E. (2005). Climate effects on the formation of jellyfish and ctenophore blooms: a review. J MarBiol Assoc UK 173 85:461-476.

26. Purcell, J.E., Uye, S.I., Lo, W.T. (2007). Anthropogenic causes of jellyfish blooms and their direct consequences for humans: a review. Mar Ecol Prog. Ser 350: 153-174.

27. Rosa, S. M., Pansera, A. Granata, L. Guglielmo. (2013). Interannual variability, growth, reproduction and feeding of Pelagia noctiluca (Cnidaria: Scyphozoa) in the Straits of Messina (Central Mediterranean Sea): Linkages with temperature and diet. Journal of Marine Systems, 111-112: 97-107. 
28. Russell, F.S. (1970). The Medusae of the British Isles. II. Pelagic Scyphozoa with a Supplement to the First Volume on Hydromedusae. Cambridge University Press, Cambridge: 284.

29. Vučetić, T. (1984). Some causes of the blooms and unusual distribution of the jellyfish Pelagia noctiluca in the Mediterranean (Adriatic). UNEP: Report on the workshop on jellyfish blooms in the Mediterranean; Athens, 31 Oct-4 Nov 1983, pp 167-176

30. Zavodnik, D. (1987). Spatial aggregations of the swarming jellyfi sh Pelagia noctiluca (Scyphozoa). Mar Biol 94:265-269.

31. Zavodnik, D. (1991). On the food and feeding in the northern Adriatic of Pelagia noctiluca (Scyphozoa). UNEP: Jellyfish blooms in the Mediterranean proceedings of the II workshop on jellyfish in the Mediterranean Sea MAP Tech Rep Ser, No 47. UNEP, Athens, pp 212-216. 